\title{
Beyond 'Badges of Honour': young people's perceptions of their anti-social behaviour orders
}

\author{
Kate Brown* \\ University of Leeds
}

\begin{abstract}
Although 'Anti-Social Behaviour Orders' (ASBOs) are likely be dropped by the Coalition government, young people considered to behave 'anti-socially' will continue to be disciplined using alternative legal measures and sanctions (Home Office, 2011). Despite the high profile public debate around ASBOs, independent empirical research into the perceptions of young people who have been served with them has remained limited. This article reports from a small-scale study which investigated how young people with ASBOs experience them. Contrary to populist notions, participants took them very seriously, revealing themselves as involved in an ongoing process of compliance and defiance with the terms of their orders. I argue that there is a need to move beyond dichotomous presentations of young people with ASBOs as either 'vulnerable victims' or 'dangerous wrong-doers', towards a more nuanced appreciation of the complex way in which transition to adulthood, vulnerability, transgression and ambivalence are woven together in their lives.
\end{abstract}

Keywords: young people, youth, anti-social behaviour, perpetrators, Anti-Social Behaviour Orders.

\section{Introduction}

Although the Coalition government announced their intention to 'move beyond the ASBO' last July (Home Office, 2010a), a concern with the 'anti-social behaviour' of young people is still firmly rooted in political, public and media rhetoric and looks set to become one of the enduring legacies of New Labour. A recent Home Office consultation paper on anti-social behaviour strategy suggests that Anti-Social Behaviour Orders (ASBOs) will be dropped, but will be replaced by alternative powers such as 'Criminal Behaviour Orders' and 'Crime Prevention Injunctions' (Home Office, 2011). Like ASBOs, these orders will prohibit individuals from certain behaviours using legal measures, with breaches involving sanctions. A desire for more effective support to deal with the 'underlying causes' of 'anti-social' behaviour has been indicated (Home Office, 2011; 10), but young people considered to be transgressive seem set to continue to be disciplined through policies similar to ASBOs in nature. 
ASBOs have been extensively studied by academics (Burney, 2005; Squires and Stephen, 2005; Squires, 2008a; Koffman 2006; Millie 2009a), but independent empirical research undertaken with young people who have been served with these orders remains relatively limited. Most existing published work has either been commissioned from within the criminal justice system (Solanki et al., 2006), has drawn particularly on the experiences of those young people confined within prisons and detention centres (Wain and Burney, 2007), or has formed part of investigations of ASBOs where young people are considered along with adults rather than as a particular case (Matthews et al., 2005; Wain and Burney, 2007). In his pilot study, McIntosh (2008) explored young people's experiences of ASBOs specifically, but as this work included only two young men, the author takes a cautious approach to inferring generalisations.

The present paper reports from a small-scale and exploratory study which investigated how ASBOs are perceived and experienced by young people who have been served with them. The aim of the project was to add to the small body of empirical work exploring 'perpetrator' perspectives of this group as distinct from adults, with a particular focus on the views of those young people located in their own environment and outside the custodial system. At the time of the research, the author was employed within support services for 'vulnerable' young people in the city where the study took place, so the investigation was grounded in connections into and knowledge of a particular local context. The approach was influenced by ideas about the 'social construction of childhood', a standpoint which emphasises children and young people's role as participant agents in social relations where they are often sidelined due to socio-economic status and other conventions (see Mayall, 2002; Jenks, 1982; James and Prout, 1990). The investigation set out from a commitment to children and young people's social worlds as having meaning in their own right, rather than seeing these as fantasies or incomplete imitations of the adult state of being. This article does not claim to represent the 'truth' about how young people are affected by ASBOs. The purpose of the study was to accept and report young people's perspectives, on the understanding that seeking to appreciate how young people make sense of ASBOs can offer valuable insights when viewed alongside other research carried out in this field.

The paper begins with a brief summary of key academic literature relevant to young people and ASBOs in England. It then outlines the local context for the study and gives an overview of research methods before presenting findings centred on three themes: i) the serious consequences which young people felt they experienced as a result of their ASBOs, ii) the complex relationship in young people's narratives between blame and culpability and iii) the co-existence of issues of compliance and defiance. Concluding remarks argue the need to move beyond dichotomised and simplistic presentations of young people with ASBOs, with some brief reflections on policy implications of findings included.

\section{ASBOs and Young People}

ASBOs were introduced in the 1998 Crime and Disorder Act, and were to become was one of the cornerstones of New Labour's crime and disorder strategy (Donoghue 2010; Millie, 2009a; Burney, 2005; Squires and Stephen, 2005). These civil orders have prohibited individuals from certain activities (criminal or non-criminal) or specific areas, with a breach of the order treated as a criminal offence. ASBOs use civil law to control behaviour based on threat posed by future potential harms. No crime need necessarily have been committed at the time of the intervention, so their logic resonates with what is sometimes called the 'precautionary principle' (Crawford, 2009a; 818). Born from New Labour's conditional vision for citizenship, the 'rights and responsibilities' agenda 
and rising concern for the cumulative effect of low-level nuisance, ASBOs were an attempt to discipline individuals whom the government considered had failed considerably in their duty to behave according to moral norms (see Burney, 2005; Millie, 2009a; Squires and Stephen, 2005). The behaviour which ASBOs have been used to address has varied widely (Hewitt, 2007), which is often attributed to antisocial behaviour being a vague, nebulous and relative concept (Nixon, 2005). ASBOs were originally conceptualised on the basis of being linked to support, but take up of supportive orders alongside disciplinary interventions has been 'very low' (Home Office, 2011: 9).

Although juvenile nuisance has been a long-standing public concern (Cohen, 1973; Pearson, 1983), the use of ASBOs with young people has enshrined and legitimised public fears into political concerns (Burney, 2005; Squires and Stephen, 2005; Squires, 2008b). For its supporters, the ASBO represents an attempt to confront the corrosive and distressing cumulative impact of young people's misbehaviours, in the context of a deterioration in conduct amongst young people (Donoghue, 2010). For critics and civil liberties groups, ASBOs are a symbol of the contemporary 'demonisation' of young people (Squires, 2008b; Cobb, 2007; Liberty, 2011; Reitemeier, 2011), in a society where 'youths' have always misbehaved, but due to changing context, there is growing concern about this (see Millie et al., 2005; Burney, 2005).

Legal commentators have argued that ASBOs contravene human rights (Burke and Morrill, 2002; Ashworth, 2004), European law (Hewitt, 2007; Ashworth 2005), and the UN Convention on the Rights of the Child (Hewitt, 2007), with concerns being raised about their proportionality and 'hybrid' nature (Hewitt, 2007). Anti-social behaviour strategy has also received criticism due to the over-representation of marginalised groups amongst ASBO subjects (Fryson and Yates, 2011; Maunders, 2010, Nixon and Hunter, 2001; Nixon et al., 2007), especially in terms of the high proportion being served on young people who have diagnosed mental health problems (BIBIC, 2005). The so-called 'naming and shaming' publicity which often accompanies ASBOs has been a particular focus for controversy (Cobb, 2008; Thomas, 2005). More generally, the anti-social behaviour agenda has been seen by some as part of a 'net widening' process (Rodger, 2008; Millie, 2009a, Crawford, 2009b), which has also entrenched inequalities by locating responsibility for resolving 'problem' behaviour in communities where it is manifested (Flint, 2006). Despite this, the intervention has proved popular with the public (Millie et al., 2005).

The social climate in which the concept of 'anti-social behaviour' has flourished has been extensively chronicled by academics (see Squires, 2008b; Rodger, 2008; Squires and Stephen 2005; Burney, 2005). Pertinent themes in this work include a move towards tougher discipline of the poorest through social welfare institutions (Millie, 2009a; Rodger, 2008), increased risk consciousness and fear of crime (see Beck, 1992; Giddens, 1990; Garland, 2001) and social problems being increasingly understood in terms of the behaviour of individual actors rather than social or material conditions (Squires, 2008b; Rodger, 2008). In terms of contemporary responses to 'deviant' children and young people in social policy, there is a substantial body of work which identifies problems and weaknesses within the dominant 'risk-focussed' paradigm in Youth Justice (see Prior and Paris, 2005). A failure to explore links between criminal behaviour and 'structural' factors such as poverty, unemployment, housing and poor neighbourhoods is a particularly notable academic criticism emerging from this literature. Although concern about children's welfare has proliferated in recent decades, so has a focus on strict behaviour control (Rodger, 2008). A dichotomous sense of those under eighteen tends to prevail in policy; with this group being seen as either passive, incompetent and 'vulnerable', or as being granted full 
agency in the case of 'wrong-doing' (Such and Walker, 2005; Piper, 2008; Fionda, 1998).

Despite the fact that around 40\% of ASBOs have been served on those under 18 (Home Office, 2010b), surprisingly little empirical research has been undertaken with young people who have been issued with these orders This may be due in part to the significant challenges noted by those who have attempted to engage young people with ASBOs in their sample groups (Mclntosh, 2008; Wain and Burney, 2007). A Youth Justice Board (YJB) qualitative study into the impact of ASBOs on young offenders in England and Wales is perhaps the most extensive work to date, based on 45 interviews with young people with ASBOs who were accessed through Youth Offending Teams (Solanki et al., 2006). As well as offering a summary of young people's feelings about their orders, the YJB's research found that some parents and carers felt that young people saw their orders as a 'badge of honour' (p. 136). The report did not find that young people themselves reported that they saw their ASBOs as symbols of status, but through incorrect media citation this study seems to have been where the now notorious notion that young people are proud of their orders originated. McIntosh's (2008) article on 'ASBO Youth' takes a case-study approach, discussing findings from interviews with two young men served with ASBOs. This study offers insights into the apparent complexity of the anti-social behaviour regulation to young ASBO recipients, and into their 'fractured backgrounds' (p. 244). A very brief reflection on the histories of young people with ASBOs was also published by Varnfield (2005), emphasising their 'vulnerability'.

Aside from these studies, research has tended to investigate the impact ASBOs have on both adults and young people (Matthews et al., 2007; Wain and Burney, 2007). The result is an inclination towards the distinctiveness of young people as a 'case' being lost within a more general picture. This to some extent reflects anti-social behaviour policy approaches to age and childhood; where young people tend lose their status as 'becoming-adults' and are granted full agency at the point of 'wrong-doing' (Such and Walker, 2005). Wain and Burney's (2007) Manchester investigation included nine young people and 11 adults in its total sample of 21 interviewees, but only three of the young people were at liberty due to problems engaging with young people who were not incarcerated. Further work in this area has tended to focus on anti-social behaviour or control order powers such as Dispersal Orders and Acceptable Behaviour Contracts (for examples see Smithson and Flint, 2006; Goldsmith, 2008; Crawford 2009b). The studies referenced above highlight the availability of selected valuable reports on young people's views of their ASBOs, but the number of investigations remains small, with young people's experiences often incorporated within more general studies. Independent research from an individual case-level perspective can lend valuable insight into how young people experience their orders, when viewed alongside other studies.

\section{The study}

A northern city was selected as a case-study site for the investigation, due to its relatively large-scale activities disciplining anti-social behaviour, and because the author was employed in youth services within this city. By 2009, the local authority within which the city was located was amongst the five authorities issuing the highest number of ASBOs to young people across England, with over 300 ASBOs having been served on young people in the city by June 2009 (e-mail correspondence with local AntiSocial Behaviour Unit, 2009). 
Six semi-structured interviews with young people under the age of 18 who had been served with ASBOs were undertaken, during the summer of 2009. Participant recruitment was undertaken via two agencies: the local authority's Anti-Social Behaviour Unit, the agency administrating and enforcing ASBOs for both adults and children in the city, and a Family Intervention Project (FIP), an agency supporting families where children are classified as having 'problem' anti-social behaviour. Four of the six young people were recruited through the FIP in order to try to access informants outside what they would be likely to perceive as the formal criminal justice system (which may engender specific responses to the ASBO). The Youth Offending Service (YOS) was avoided as an access agency for this reason, but the Anti-Social Behaviour Unit was less directly implicated. Interviews lasted around an hour and took place mainly at the offices of support services located in the young person's local area, with one conducted at a young person's home. Young people were asked informally about what led to their ASBO, experiences of the process of being served with one, the impact it had on their lives and their feelings about these issues. Instances of breaches and future aspirations were also discussed. In three of the interviews, a third party (support worker or parent) was present for part or all of the interview, as FIP staff advised that it was unlikely that certain young people would speak about their experiences in a meaningful way without someone else present whom the young person knew and trusted.

The ages of participants ranged from 13 to 16, whilst ASBOs were from two to four years in duration. All of the interviewees had been subject to ASBOs for at least a year. The sample deliberately focussed on the group who are the primary receivers of ASBOs in the city, white working class young men, whose masculinities have been of interest to a growing number or researchers in recent years (see Fletcher 2007, McDowell 2003, Sveinsson, 2009). All six interviewees were young men, all six were of 'white UK' ethnic origin and two were brothers. Extending the study to young women and young people from black and minority ethnic backgrounds would have been extremely difficult given the timescales of the study, the low numbers of ASBO recipients from these groups, and the already 'difficult-to-reach' nature of the overall client group. Clearly, findings should be understood in this context and work on female and 'non-white' ASBO 'perpetrators' is an area where further study is needed.

Five of the six young men in the study disclosed that they had offending histories. As in other studies undertaken with this group, similarities were evident in terms of what research has highlighted are the personal and social circumstances of young people involved in the criminal justice system (see Solanki et al., 2006; Matthews et al., 2007). All of the young men had educational histories characterised by exclusions and truanting. Three were in the education system, two were 'Not in Education, Employment or Training' and one young man was in transition between a Pupil Referral Unit and Further Education college. The participants all lived on housing estates, with five being accommodated in social housing. Family histories were complicated and often apparently chaotic. Four of the young men lived in single parent households with their mother and siblings, one lived with his mother, father and brother, and one with his mother, stepfather and siblings. Heroin use was evident as a factor in three young people's family backgrounds, in immediate or extended families.

\section{Findings from interviews}

Pertinent issues from young people's reports are referred to under three sub-headings below, though these were closely linked. Respondents are identified by names and ages, with names having been changed to provide anonymity. 


\section{i) Serious consequences}

The young people indicated that they largely took their ASBOs very seriously, due to the punishments they had experienced for breaches, and the impact their orders had on their families.

I didn't know I was getting an ASBO at first, me. It sort of come; we're giving you this and we're giving you this, that and t' other. And I thought 'oh right then'. I never thought an ASBO were bad at all really, but it is. It can get you kicked out your house, sent to prison... ah, loads o' stuff. (Matthew, 16)

This quotation raises the issue of a lack of understanding about the process of being made subject to an ASBO which has been highlighted in other studies (see Mclntosh, 2008). It may be that due to poor initial understandings of ASBO conditions, the stage at which young people are asked to reflect on their order may affect their views of how restraining they find it.

The stress which young people perceived their ASBOs causing for their parents mothers in particular - was one of the most significant consequences reported by interviewees. Their mother's eviction or threatened eviction was one of the things that upset four of the young people most about their ASBOs. Threatened eviction of their mothers (see Nixon and Hunter, 2001), although perceived as an injustice, was one of the primary reasons cited by young people in efforts to stop breaching their ASBOs:

I wouldn't be bothered if every time we got locked up it just happened to us whatever was gonna happen, but when it goes down on me mum, that's what does my 'ed in (Dylan, 14).

Matthew (16) felt his anti-social behaviour was responsible for the breakdown of his mother's mental health:

She nearly had to go ont' nutty wing. That's how poorly she got. She started going dingy.

Earlier in the same interview he had also implied that his mother lacked the power to control his behaviour:

She used to get stressed and that and I used to just laugh at her and get her more mad and then just walk out.

That some of the young people presented a mixture of defiance of and care and concern for parents perhaps adds a further dimension to findings in other studies which indicate that young people show 'little concern' about the impact of their ASBOs on their families (Wain and Burney, 2007: 81).

Each of the young men said that they had been disciplined for breaching their orders from a minimum of one to a maximum of seven times. What were perceived as harsh punishments had been experienced as a result of these breaches, usually custodial sentences, curfews and tags. Their ASBOs were seen by the young men to severely limit their freedom. Particularly problematic for them were restrictions on being able to see their closest friends ('non-association clauses') and geographical exclusions:

Can't do nowt now. Can't go anywhere, hang around with us mates like I used to before. Just have to stay in most o't time, or stay on our street (Dylan, 14).

The feasibility of adhering to ASBO conditions was questioned by four of the six young people, but 'trying hard' to comply with the terms of their orders was still noted 
as a priority due to the serious consequences they felt would ensure for future breaches.

Of the six interviewees, five had experienced their ASBOs publicised on flyers in the local community, which could elicit strong feelings of embarrassment, shame and suggestions that ASBOs stigmatised them in some way, as consistent with Wain and Burney's (2007) study. As Matthew (16) put it:

I felt bad, me... I didn't want everyone knowing who I was and now everyone knows who we are.

Matthew said that public notices about his ASBO made him feel, 'not good at all', but he was the only interviewee who also indicated an element of bravado as well as negative feelings at another point in the interview:

Me mum were carryin' on... I were sayin’ 'look mum, your son's famous, look at me picture'. I thought it were funny, but she din't find it funny at all.

Laughter has been previously highlighted as a coping strategy and distancing technique amongst stigmatised groups (Sanders, 2005), and that one young person can hold such contradictory views of his response to his ASBO within the same interview may suggest the existence of various 'presentations of the self' which individuals employ when stigmatised in society (Goffman, 1959 and 1963). Although this bravado and mixed attitude was not expressed by the other young people, this exception will be further explored further in the final part of the article given the notoriety attached to the idea that young people see their orders as 'badges of honour'.

\section{ii) Blame and culpability}

A complex relationship between blame and culpability emerged through the young people's stories. Their narratives contained recognition of instances where they felt they had behaved badly, alongside a sense of injustice stemming from the feeling that their ASBOs exposed them to unfair and false accusations. Josh (16) vehemently denied an incident of motorbike riding that was brought against him in court when his ASBO was served, adding, 'And I do admit the things I did'. Two young people felt they were blamed (instead of other young people who were also involved in incidents) because of their reputation:

I do it and it's probably me that gets caught 'cos they know me and they don't know the others like... I don't grass on em' (Jamie, 13)

This was consistent with cases of 'scapegoating' identified in other work (Wain and Burney, 2007: 103).

Where they described ASBO breaches relating to committing criminal offences (which were offences in their own right; such as robbery), young people acknowledged that these incidents deserved serious consequences. Where young people were subject to criminal sanctions for ASBO breaches that resulted from behaviours that were not criminal in themselves, these punishments were experienced as being disproportionate and unfair. In separate interviews, Josh (16) and Dylan (14) explained that they were 'breached' after joining a crowd watching a house on their street being 'raided' by the police, for which they reported receiving a sentence of being electronically tagged for three months, with a curfew time of 7 o'clock in the evening.

Stories of mistaken identity were common. Most of the young men detailed being charged with ASBO breaches where they had not breached and were not even in the vicinity of the incident in question. One situation like this was explained as follows: 
p. 19. Beyond 'Badges of Honour': Young People's Perceptions of their Anti-Social Behaviour Orders

One of 'em [police officers] arrested me for a burglary that I didn't do. Just 'cos I fitted the description. And he knew that l'd just come home from school. I came home from school, got dropped off at me Aunty's house by me teacher, I were in me Aunty's house for about twenty minutes and he arrested me. (Aaron, 16)

Several young people also highlighted how their ASBO enabled some people in the local community to challenge their freedom to exercise harmless behaviour as well as 'harmful' behaviour. Matthew (16) reported being charged with an ASBO breach after a snowball fight where other young people had misinformed the police that there were bricks inside the snowballs he had been throwing, which he was arrested for. Interviewees often accepted their own role in the creation of a dynamic of being blamed for things they did not do, but also resented being treated unfairly. As Josh (16) put it:

They know they can get you on 'owt. They can lock you up and just get you charged with 'owt anyway. 'Cos you're not allowed to do nowt on't ASBO.

Narratives paralleled research findings noting that anti-social behaviour interventions with young people can result in increased hostility between young people and the police in their locality (Smithson and Flint, 2006). Feeling victimised was a frequently occurring response when young people recalled incidents with the police, along with a lack of power to address this victimisation. Josh (16) recalled that in one incident his head was 'smashed' into a gate by police officers, resulting in a 'bust lip'. His brother witnessed this, but chose not to complain;

You can't win anyway with 'em. 'Cos there's loads of police officers, they can say they've got loads of thingie - witnesses - but we din't have that much witnesses, we only had about two witnesses or summut (Dylan, 14).

Apart from antagonism with the police, of most concern for young people about their ASBO's 'fairness' was a questioning of its legitimacy based on two things; times where they were punished for incidents that were not breaches of their ASBO, and instances where they had been singled out for treatment that other young people behaving similarly did not receive.

\section{iii) Compliance and defiance}

Non-compliance with ASBOs is one of the criticisms most notable in the media and in recent governmental concerns with the intervention (Home Office, 2011 and 2010a). Wain and Burney's study reported on this issue; 50 per cent of ASBO recipients in their research had breached their order at least once $(2007 ; 128)$ and reasons for noncompliance were explored. Much less consideration has been given to how young people comply with their orders, and in particular, how they view periods or instances of compliance. Despite stories of multiple breaches, overall, trajectories of compliance tended to dominate young people's narratives. All interviewees reported moving towards increased adherence to the terms of their ASBOs, even if they were not confident of sticking to the requirements completely and had not done in the past. Only Matthew (16) reported still openly flouting one part of his ASBO's conditions:

No one's gonna stop me hangin' about with me mates - not even an ASBO. Cos I do it anyway.

The role of ASBOs in changing behaviour was difficult to separate from the influence of other changes in young people's lives. For example, Aaron (16) had recently had a child with his girlfriend. Though he reported that his ASBO had been crucial in changing his behaviour, in the same interview he later attributed this change to becoming a father. Stories about adherence to ASBOs supported theories about desistance from 
transgressions being linked to increasing responsibilities, and securing masculinity from other sources, fitting with the idea that some young people 'grow out of crime' (Henderson, 1994; Stephen and Squires; 2005). As Matthew (16) indicated:

[ASBO] hasn't changed nowt. I just do what I do everyday... But I'm not a little kid no more, I don't go round smashin' windows or actin' childish or owt like that. l've grown up a bit now.

The complexity of the role of the ASBO as a change agent reflects the prevalence of transition and ambivalence in young people's lives, which may be particularly pronounced amongst those young people who are 'socially excluded' (Johnston et al., 2000). There was a notable mixture of resistance to social control and compliance with accepted norms. Five interviewees had a strong desire to work and earn a living and one to 'get a good education', three wanted careers in construction, one was waiting to join the army at sixteen, and one hoped to be a fireman. In instances where young people reported that their ASBOs had helped them in some respects, this was usually connected to a sense that it had helped them to stay away from trouble, and they valued this. Portrayals of young people with ASBOs as uniformly 'deviant' were contradicted by the conformist 'imagined futures' and aspirations of the young men in the study.

\section{Concluding Remarks}

This discussion piece has provided additional insights at case-level into young people's own perspectives of their ASBOs. Participants in this study reported that they took their ASBOs extremely seriously. They felt they had experienced harsh punishments for breaches, and orders were seen as severely restricting their everyday activities as well as negatively affecting the well being of their families. The degree to which ASBOs acted as 'change agents' in young people's lives was difficult to assess, although in this snapshot of their lives, interviewees generally depicted themselves as moving towards more compliant behaviours. Blame and culpability were mixed together in the minds of young people, with narratives containing both recognition of instances where they felt they had behaved badly, and also a notable sense of unfairness resulting from times where their ASBOs exposed them to false accusations.

These findings call into question the now notorious theory that ASBOs function as 'badges of honour' for young people. Alongside this, interesting issues are raised about the difficulty of establishing 'truth' in young people's stories. Generally speaking, ASBO publicity was a source of shame, but one young man did exhibit both bravado and feelings of embarrassment in the same interview. Goffman (1959), in his analysis of stigma, argues that role-playing behaviour is often employed a means to create a specific impression in the minds of others. He describes 'front stage' as a situation were someone takes on a specific role before an audience based on the expectations placed on him or her and 'backstage' as a secure zone where the performer is not under pressure to maintain a role. As the need for impression management is highest in contexts where the individual is labelled deviant (Goffman, 1963), this perhaps offers some insight into how a tension between bravado and admissions of shame can be explained and reconciled.

Young people with ASBOs are portrayed in policy as lacking moral integrity, a sense of their responsibilities, and the ability to exercise moral judgement (Such and Walker, 2005). In the present study, young people appeared as reflexive moral agents, aware of the implications of their conduct and able to engage in self-examination; an appearance which challenges presumptions of moral incompetence evident in antisocial behaviour policy. At a time when many young people feel alienated from policy 


\section{p. 21. Beyond 'Badges of Honour': Young People's Perceptions of their Anti-Social Behaviour Orders}

agendas due to what they perceive as a lack of respect for their own concerns and negative portrayals of them (Children's Rights Alliance for England, 2008; UK Children's Commissioner's Report, 2008; Youth Net and British Youth Council, 2006), recognising and building on young people's sense of moral identity in 'anti-social behaviour' policy and practice may encourage less resentment and resistance on the part of young people subject to such forms of social control.

However, recognising a greater degree of moral agency must not be confused with granting young people the same agency as adults in instances of wrong-doing, as is often the case in anti-social behaviour policy (Such and Walker, 2005). Alongside accounts of behaviour considered criminal and 'anti-social', young people showed vulnerability and sensitivity through their narratives. 'Vulnerability' is largely assumed to be an essential quality of childhood and adolescence (Daniel, 2010), which this group tend to be presented as either subsumed by (Varnfield, 2005) or exempt from due to their status as socially 'deviant' (Such and Walker, 2005; Piper, 2008). This study suggested that young people with ASBOs are vulnerable as well as transgressive, resistant as well as compliant, and morally reflexive as well as challenging. When 'moving beyond the ASBO', the opportunity should be taken to move beyond simplistic and dichotomised constructions of young people who are served with them.

If achieved in practice, Government plans to place more emphasis on supportive interventions alongside prohibitive orders may go some way to addressing young peoples' sense of disproportionality about the harsh punishments they feel they experience for breaching their orders (Home Office, 2011). A shift like this might to some degree enhance the legitimacy of the anti-social behaviour disciplinary process in the eyes of young people. An appreciation of young people's experiences of compliance with legal orders as a dynamic rather than static process would also be helpful in the design and evaluation of future interventions in this area. More generally though, when the 'vulnerability' and moral reflexivity of 'anti-social' young people is seen alongside their capacity to be transgressive, any strategy of forcing behavioural change on this group through legal measures remains ethically contentious. There are no easy policy prescriptions, but in terms of social justice, acknowledging the destructive impact of the behaviour of some young people does not necessarily justify coercive enforcement techniques to stop them engaging in activities (Fitzpatrick and Jones, 2005). An 'inclusive' society is now generally seen as an aspiration in social policy (Lister, 2000). To achieve an outcome where the interests of relatively powerless young people considered 'anti-social' are not consistently overridden by those in a more powerful position, further attention must be given in policy to understanding the social worlds of so-called 'perpetrators' of 'anti-social behaviour', and of young people more generally.

\section{Acknowledgements}

The author wishes to thank the young people who took part in the study and the local organisations who facilitated interviews. I am also grateful to Malcolm Harrison and Teela Sanders for their comments on drafts of this paper and continued support.

* Correspondence Address: Kate Brown, School of Sociology of Social Policy, University of Leeds, Leeds, LS2 9JT. Email: k.e.brown@leeds.ac.uk. 
p. 22. Beyond 'Badges of Honour': Young People's Perceptions of their Anti-Social Behaviour Orders

\section{References}

Ashworth, A. (2004) Social control and "anti-social behaviour": the subversion of human rights? Law Quarterly Review, 120, 263-291.

Ashworth, A. (2005) Anti social behaviour orders. Criminal Law Review, 292-293.

Beck, U. (1986) Risk Society: Towards a New Modernity. London: Sage.

BIBIC (2007) BIBIC research on ASBOs and young people with learning difficulties and mental health problems. Bridgewater: BIBIC.

Burney, E. (2005) Making People Behave: Anti-Social Behaviour, Politics and Policy. Cullumpton: Willan.

Burke, R. and Morrill, R. (2002) Anti-Social Behaviour Orders: An Infringement of the Human Rights Act 1998? Nottingham Law Journal, 11, 2, 1-16.

Children's Rights Alliance for England (2008) Get Ready for Geneva: Submission to the UN Committee on the Rights of the Child. London: CRAE.

Cohen, S. (1972) Folk Devils and Moral Panics. London: Routledge.

Cobb, N. (2007) Governance through publicity: anti-social behaviour orders, young people and the problematization of the right to anonymity. Journal of Law and Society, 34, 3, 342-373.

Crawford, A. (2009a) Governing Through Anti-Social Behaviour. British Journal of Criminology, 49, 810-831.

Crawford, A. (2009b) Criminalising Sociability through Anti-social Behaviour Legislation: Dispersal Power, Young People and the Police. Youth Justice, 9, 1, 5-26.

Daniel, B. (2010) Concepts of Adversity, Risk, Vulnerability and Resilience: A Discussion in the Context of the 'Child Protection System'. Social Policy and Society, 9, 2, 231-241.

Donoghue, J. (2010) Anti-social behaviour orders: a culture of control? Basingstoke: Palgrave Macmillan.

Fionda, J. (1998) Case commentary: The age of innocence? The concept of childhood in the punishment of young offenders ( $R \vee$ Secretary of State for the Home Department ex parte Venables and Thompson). Child and Family Law Quarterly, 10, 1, 77-87.

Fitzpatrick, S. and Jones, A. (2005) Pursuing Social Justice or Social Cohesion? Coercion in Street Homelessness Policies in England. Journal of Social Policy, 34, 3, 389-406.

Fletcher, D. (2007) Offenders in the post-industrial labour market: lubricating the revolving door? People, Place and Policy, 1, 2.

Flint, J. (2006) Maintaining an Arm's Length? Housing, Community Governance and the Management of 'Problematic' Populations. Housing Studies, 21, 2, 171-186.

Fryson, R. and Yates, J. (2011) Anti-Social Behaviour Orders and young people with learning disabilities. Critical Social Policy, 31, 1, 102-125.

Garland, D. (2001) The Culture of Control. Oxford: Oxford University Press.

Giddens, A. (1990) The Consequences of Modernity. Cambridge: Polity.

Goldsmith, C. (2008) Cameras, cops and contracts: what anti-social behaviour management feels like to young people, in: P. Squires (ed.) ASBO Nation: The Criminalisation of Nuisance. Bristol: The Policy Press.

Goffman, E. (1959) The Presentation of the Self in Everyday Life. New York: Anchor.

Goffman, E. (1963) Stigma: Notes on the Management of Spoiled Identity. EnglewoodCliffs, NJ: Prentice Hall.

Henderson, J. (1994) Masculinity and Crime: The implications of a gender conscious way of working with young men involved in 'joyriding'. Social Action, 2, 2, 19-25.

Hewitt, D. (2007) Bovvered? A legal perspective on the ASBO. Journal of Forensic and Legal Medicine, 14, 6, 355-363.

Home Office (2010a) Moving Beyond the ASBO. Speech by Theresa May to Colin Street Community Centre, $28^{\text {th }}$ July. London: The Conservatives. 
p. 23. Beyond 'Badges of Honour': Young People's Perceptions of their Anti-Social Behaviour Orders

Home Office (2010b) Anti Social Behaviour Orders Statistics 2009. Home Office Research and Development and Statistics Website, http://rds.homeoffice.gov.uk/rds/stats-release.html. Accessed 28th February 2011

Home Office (2011) More Effective Responses to Anti-social Behaviour. London: Home Office.

James, A. and Prout, A. (1990) Constructing and Reconstructing Childhood: Contemporary Issues in the Sociological Study of Childhood. London: Falmer.

Jenks, C. (ed) (1982) The Sociology of Childhood: Essential Readings. London: Batsford.

Johnson, L., MacDonald, R., Mason, P., Ridley, L. and Webster, C. (2000) Snakes and Ladders: Young people, transitions and social exclusion. Bristol: The Policy Press.

Koffman, L. (2006) The Use of Anti-Social Behaviour Orders: An Empirical Study of a New Deal for Communities Area. The Criminal Law Review, 593-613.

Liberty (2011) Website Statement on ASBOs and Young People. http://www.libertyhuman-rights.org.uk/human-rights/discrimination/young-people/index.php. Accessed 28th February 2011.

Lister, R. (2000) Strategies for Social Inclusion: Promoting social cohesion or social justice? In: P. Askonas and A. Stewart (eds.) Social Inclusion: Possibilities and Tensions. Basingstoke: Macmillan.

Matthews, R., Easton, H., Briggs, D. and Pease, K. (2007) Assessing the use and impact of Anti-Social Behaviour Orders. Bristol: The Policy Press.

Maunders, G. (2010) The use of Anti-Social Behaviour Powers with Vulnerable Groups: Some Recent Publications. Social Policy and Society, 9, 1, 145-153.

Mayall, B. (2002) Towards a Sociology for Childhood. Thinking from Children's Lives. Buckingham: Open University Press.

McDowell, L. (2003) Redundant Masculinities? Employment Change and White Working Class Youth. Oxford: Blackwell Publishing.

Mclntosh, B. (2008) ASBO Youth: Rhetoric and Realities, in: P. Squires (2008) ASBO Nation: The Criminalisation of Nuisance. Bristol: The Policy Press.

Millie, A., Jacobson, J., McDonald, E. and Hough, S. (2005) Anti Social Behaviour Strategies: Finding a balance. Bristol: Policy Press.

Millie, A. (2009a) Anti-Social Behaviour. Maidenhead: Open University Press.

Millie, A. (2009b) Securing respect: behavioural expectations and anti-social behaviour in the UK. Bristol: Policy Press.

Nixon, J. (2005) ASBOs: More Questions than Answers. Criminal Justice Matters, 62, 1, 22-37.

Nixon, J. and Hunter, C. (2001) Taking the blame and losing the home: women and anti-social behaviour. Journal of Social Welfare and Family Law, 23, 4, 395-410.

Nixon, J., Hodge, N., Parr, S., Willis, B. and Hunter, C. (2007) Anti-Social Behaviour and Disability in the UK. People, Policy, Place Online, 2, 1, 37-47.

Piper, C. (2008) Investing in Children: Policy, Law and Practice in Context. Devon: Willan Publising.

Prior, D. and Paris, A. (2005) Preventing Children's Involvement in Crime and AntiSocial Behaviour: A Literature Review. EFeS Research Report 623. Nottingham: DfES.

Pearson, G. (1983) Hooligan: A History of Respectable Fears. Basingstoke: Macmillan.

Reitemeier, B. (2011) Quoted in The Guardian: 'ASBO replacement orders condemned by children's charities. $7^{\text {th }}$ February 2011, www.guardian.co.uk. Accessed $28^{\text {th }}$ February 2011.

Rodger, J. (2008) Criminalising social policy: anti-social behaviour and welfare in a decivilised society. Cullompton: Willan.

Sanders, T. (2005) Controllable Laughter: Managing Sex Work through Humour. Sociology, 38, 273-291. 
Smithson, H. and Flint, J. (2006) Responding to Young People's Involvement in AntiSocial Behaviour. Youth and Policy, 93, 21-39.

Solanki, A., Bateman, T., Boswell, G. and Hill, E. (2006) Anti Social Behaviour Orders. London: Youth Justice Board for England and Wales.

Squires, P. and Stephen, D. (2005) Rougher Justice. Cullompton: Willan Publishing.

Squires, P. (2008a) ASBO Nation: The Criminalisation of Nuisance. Bristol: The Policy Press.

Squires, P. (2008b) The Politics of Anti-Social Behaviour. British Politics, 3, 300-323.

Such, E. and Walker, R. (2005) Young citizens or policy objects? Children in the "rights and responsibilities" debate. Journal of Social Policy, 34, 1, 39-57.

Sveinsson, K. (2009) Who cares about the white working class? London: The Runnymede Trust.

Thomas, T. (2005) The Continuing Story of the ASBO. Youth and Policy, 87, 5-14.

UK Children's Commissioner's Report (2008) UK Children's Commissioner's Report to the UN Committee on the Rights of the Child. London: UK Children's Commissioners.

Varnfield, K. (2005) Vulnerable young people and the misuse of ASBOs. Community Safety Journal, 4, 1, 33-37.

Wain, W. and Burney, E. (2007) The ASBO Wrong Turning- Dead End. London: Howard League for Penal Reform.

Youth Net and British Youth Council (2006) Respect? The Voice Behind the Hood: Young People's Views on Anti-Social Behaviour, the Media and Older People. London: Youth Net; The British Council. 